\title{
Effect of Antioxidant Administration during Transient Period on Progesterone Profile in Surti Buffaloes
}

\author{
L.C. Modi ${ }^{1 *}$, C.T. Khasatiya ${ }^{1}$, Sandhya Chaudhary ${ }^{2}$, N.F. Chaudhari ${ }^{1}$, \\ C.F. Chaudhari ${ }^{1}$ and Falguni Modi ${ }^{3}$
}

${ }^{1}$ Department of Veterinary Gynaecology and Obstetrics, ${ }^{2}$ Department of Veterinary Physiology \& Biochemistry, ${ }^{3}$ Department of Veterinary Pharmacology \& Toxicology, College of Veterinary Science and Animal Husbandry, Navsari Agricultural University, Navsari, Gujarat-396450, India

*Corresponding author

K e y w o r d s
Antioxidant,
Transient period,
Progesterone,
Buffaloes

\section{A B S T R A C T}

The study was carried out on 20 Surti buffaloes during their transient period maintained at the Livestock Research Station, Navsari Agricultural University, Navsari, Gujarat. These animals were divided into two groups of ten each. Buffaloes of group-I were treated with Inj. Vitamin E and Selenium (E-CARE Se) on $60^{\text {th }}, 45^{\text {th }}, 30^{\text {th }}$ and $15^{\text {th }}$ day before expected date of parturition and after parturition on $15^{\text {th }}, 30^{\text {th }}$ day, while buffaloes of group-II were treated with Inj. Normal Saline as placebo treatment IM. Blood samples were collected on similar days before injection as well as on the day of parturition, $45^{\text {th }}$ and $60^{\text {th }}$ days postpartum. The mean serum progesterone concentration did not differ significantly $(p>0.05)$ at different days/phases interval in between treatment and control groups. The overall (before parturition) mean serum progesterone in the treatment group were nonsignificantly $(\mathrm{p}>0.05)$ higher as compared to control group but overall (after parturition) it was found non-significantly ( $p>0.05)$ lower in treatment group as compared to control group, respectively. Similarly, the mean serum progesterone did not differ significantly ( $>0.05)$ in between pregnant \&non-pregnant groups at different days interval except at $15^{\text {th }}$ day after parturition it was significantly $(\mathrm{p}<0.05)$ lower in pregnant group as compared to non-pregnant group of Surti buffaloes, respectively.

\section{Introduction}

The transition or periparturient period, from 3 weeks before to 3 weeks after parturition, is a stressful time for dairy cows (Drackley, 1999). The production of free radicals leads to infertility because of their effect on sterioidogenic enzymes (Miller et al., 1993), ovarian steriodogenic tissue (Margolin et al., 1990) all are sensitive to free radicles damage. During gestation oxidative stress plays a role in the initiation of pre-term labor (Pressman et al., 2003) and during normal parturition (Fainaru et al., 2002) assuring ovulation, ovarian steroidogenesis, oocyte maturation, 
blastocyst formation, luteolysis and luteal maintenance in pregnancy (Sugino et al., 2000). Vitamin E is an important antioxidant that has been shown to play an important role in immuno responsiveness and health in dairy cows (Weiss and Spears, 2006).In Vitamin E and Selenium deficiency condition, free radicals accumulate and not only damage cell membranes, but also disrupt several processes linked to the synthesis of steroids (Seagerson and Libby, 1982) and prostaglandins (Harrison and Conrad, 1984). It is not surprising therefore that negative impacts of Vitamin E and Selenium deficiencies have been observed on various components of the reproductive events, including post-partum activities (Jie et al., 2004). Steroid hormone like, progesterone is necessary for maintenance of pregnancy throughout gestation period in cattle and values are found varied during pregnancy, parturition and lactation and its estimation provides important clue about reproductive status of animals.

\section{Materials and Methods}

The present research work was undertaken on twenty (20) Surti buffaloes during their transient period i.e. two month before their expected date of parturition to two month after parturition, dividing into treatment $(n=10) \&$ control $(\mathrm{n}=10))$ groups, at Livestock Research Station, Navsari Agricultural University, Navsari, Gujarat, over a period from May, 2014 to April, 2015. The animals were fed green fodder, hay and compounded concentrate, as per the standard feeding schedule followed on the farm. The animals had free access to drinking water. The animals were also washed and sprinkled with water twice daily or were allowed to wallow in the pond during hot noon hours of summer season to reduce heat stress and to improve oestrus expression in them. In control group of 10 animals to which $10 \mathrm{ml}$ normal saline injected IM on $60^{\text {th }}, 45^{\text {th }}, 30^{\text {th }}$ and $15^{\text {th }}$ day before expected date of parturition and after parturition on $15^{\text {th }}, 30^{\text {th }}$ day. Treatment Group of 10 animals to which the injectable product E-CARE Se (DL- $\alpha$ Tocopheryl Acetate I.P. equivalent to Tocopherol (Vitamin E) Base $50 \mathrm{mg}$, Sodium Selenite U.S.P. equivalent to Selenium Base $-1.5 \mathrm{mg}$ in each $\mathrm{ml}$ ) was administered IM on $60^{\text {th }}, 45^{\text {th }}, 30^{\text {th }}$ and $15^{\text {th }}$ day before expected date of parturition and after parturition on $15^{\text {th }}, 30^{\text {th }}$ day at the dose rate of $10 \mathrm{ml}(500 \mathrm{mg}$ vit. $\mathrm{E}$ and $15 \mathrm{mg} \mathrm{Se}$.). Pregnancy diagnosis was carried out per rectally at 90 days post breeding. Again the group was made from all 20 animals irrespective of treatment and control group on the base of its conception in pregnant $(n=13)$ and non-pregnant $(n=7)$ groups.

\section{Blood collection and laboratory examination}

Blood samples were collected from all those selected animals on approximate day 60, 45, 30,15 before the expected date of parturition, on the day of parturition and 15, 30, 45 and 60 day after parturition in serum clotting vaccutainer for serum. The serum was separated from vaccutainers containing $5 \mathrm{ml}$ blood samples immediately after its collection and stored at $-20^{\circ} \mathrm{C}$ in deep freezer until analysis. Serum progesterone $\left(\mathrm{P}_{4}\right)$ concentration was measured by standard Enzyme Linked Immuno Sorbent Assay (ELISA) technique using assay kits and procedure described by Product No. DNOV006, Nova Tec Immundiagnostica GmbH Technologie \& Waldpark, Germany.

\section{Statistical analysis}

The tests of significance for pregnant vs. nonpregnant in treatment vs. control groups were made by Standard Student's paired ' $t$ ' test. The fortnight-wise variation within the group was tested for each trait by using completely randomized design as well as the mean 
differences between and within the groups were tested using Duncan's New Multiple Range Test (DNMRT) at 1 per cent and 5 per cent level of significance.

\section{Results and Discussion}

The mean serum progesterone concentration was observed to differ non-significantly between treatment and control groups at different peripartum intervals. The mean serum progesterone concentration was found non-significantly $(\mathrm{p}>0.05)$ higher at $60^{\text {th }}$ day $(3.660 \pm 0.080$ vs. $3.547 \pm 0.094 \mathrm{ng} / \mathrm{ml})$ but non-significantly $(\mathrm{p}>0.05)$ lower at $45^{\text {th }}$ day $(2.901 \pm 0.115$ vs. $3.062 \pm 0.151 \mathrm{ng} / \mathrm{ml})$ and again non-significantly $(\mathrm{p}>0.05)$ higher at $30^{\text {th }}$ day $(2.529 \pm 0.157$ vs. $2.393 \pm 0.131 \mathrm{ng} / \mathrm{ml})$ and $15^{\text {th }}$ day $(2.266 \pm 0.149$ vs. $2.170 \pm 0.142$ $\mathrm{ng} / \mathrm{ml}$ )before parturition in treatment group as compared to control group. Whereas, nonsignificantly ( $p>0.05)$ lower $(0.456 \pm 0.076$ vs. $0.515 \pm 0.110 \mathrm{ng} / \mathrm{ml})$ on day of calving and thereafter at $15^{\text {th }}$ day $(0.857 \pm 0.080$ vs. 1.128 $\pm 0.138 \mathrm{ng} / \mathrm{ml}$ ) postpartum, after that nonsignificantly $(\mathrm{p}>0.05)$ higher $(1.189 \pm 0.181$ vs. $1.008 \pm 0.130 \mathrm{ng} / \mathrm{ml})$, lower $(1.170 \pm 0.139$ vs. $1.262 \pm 0.228 \mathrm{ng} / \mathrm{ml})$ and higher $(2.083 \pm$ 0.177 vs. $1.984 \pm 0.175 \mathrm{ng} / \mathrm{ml})$ at $30^{\text {th }}, 45^{\text {th }}$ and $60^{\text {th }}$ day postpartum, respectively in treatment group as compared to control group (Table 1).

The prepartum progesterone concentrations were significantly $(\mathrm{p}<0.05)$ higher when compared between prepartum and postpartum phases at various interval in treatment and control groups, viz. at $60^{\text {th }}$ day prepartum $(3.660 \pm 0.080 \mathrm{ng} / \mathrm{ml} ; 3.547 \pm 0.094 \mathrm{ng} / \mathrm{ml})$ than that of $60^{\text {th }}$ day postpartum $(2.083 \pm$ $0.177 \mathrm{ng} / \mathrm{ml} ; 1.984 \pm 0.175 \mathrm{ng} / \mathrm{ml}) ; 45^{\text {th }}$ day prepartum $(2.901 \pm 0.115 \mathrm{ng} / \mathrm{ml} ; 3.062 \pm$ $0.151 \mathrm{ng} / \mathrm{ml})$ than that of $45^{\text {th }}$ day postpartum $(1.170 \pm 0.139 \mathrm{ng} / \mathrm{ml} ; 1.262 \pm 0.228 \mathrm{ng} / \mathrm{ml})$; $30^{\text {th }}$ day prepartum $(2.529 \pm 0.157 \mathrm{ng} / \mathrm{ml}$; $2.393 \pm 0.131 \mathrm{ng} / \mathrm{ml}$ ) than that of $30^{\text {th }}$ day postpartum $(1.189 \pm 0.181 \mathrm{ng} / \mathrm{ml} ; 1.008 \pm$ $0.130 \mathrm{ng} / \mathrm{ml})$ and $15^{\text {th }}$ day prepartum $(2.266 \pm$ $0.149 \mathrm{ng} / \mathrm{ml} ; 2.170 \pm 0.142 \mathrm{ng} / \mathrm{ml})$ than that of $15^{\text {th }}$ day postpartum $(0.857 \pm 0.080 \mathrm{ng} / \mathrm{ml}$; $1.128 \pm 0.138 \mathrm{ng} / \mathrm{ml}$ ) in both treatment and control groups of Surti buffaloes, respectively (Table 1). The pooled mean serum progesterone concentration was found to decrease significantly $(\mathrm{p}<0.05)$ trend from $60^{\text {th }}$ day $(3.603 \pm 0.061 \mathrm{ng} / \mathrm{ml})$ to $45^{\text {th }}$ day $(2.981 \pm$ $0.094 \mathrm{ng} / \mathrm{ml})$ and $30^{\text {th }}$ day $(2.461 \pm 0.101$ $\mathrm{ng} / \mathrm{ml})$ and thereafter non-significantly $(\mathrm{p}>0.05)$ at $15^{\text {th }}$ day prepartum $(2.218 \pm 0.101$ $\mathrm{ng} / \mathrm{ml})$ and significantly $(\mathrm{p}<0.05)$ decreased on the day of calving $(0.486 \pm 0.065 \mathrm{ng} / \mathrm{ml})$ and increased in trend significantly $(\mathrm{p}<0.05)$ at $15^{\text {th }}$ day $(0.992 \pm 0.084 \mathrm{ng} / \mathrm{ml})$ postpartum and thereafter increased non-significantly $(\mathrm{p}>0.05)$ at $30^{\text {th }}$ day $(1.099 \pm 0.110 \mathrm{ng} / \mathrm{ml}), 45^{\text {th }}$ day $(1.216 \pm 0.130 \mathrm{ng} / \mathrm{ml})$ and significantly $(\mathrm{p}<0.05)$ at $60^{\text {th }}$ day $(2.034 \pm 0.122 \mathrm{ng} / \mathrm{ml})$ postpartum. Almost similar trend was observed in both treatment and control groups also (Table 1).

The mean serum progesterone concentration was also found non-significantly ( $p>0.05)$ different between overall pregnant and nonpregnant groups at different peripartum intervals, except at $15^{\text {th }}$ day postpartum, where it was significantly $(\mathrm{p}<0.05)$ lower in pregnant group $(0.875 \pm 0.074$ vs. $1.211 \pm 0.176 \mathrm{ng} / \mathrm{ml})$ as compared to non-pregnant group. In the pregnant and non-pregnant group, the mean serum progesterone concentration was nonsignificantly $(\mathrm{p}>0.05)$ higher at $60^{\text {th }}$ and $30^{\text {th }}$ day prepartum as well as, at $30^{\text {th }}$ days postpartum, while rest of the days in prepartum and postpartum phase including the day of calving mean serum progesterone concentration was non-significantly $(p>0.05)$ lower in pregnant as compared to nonpregnant groups (Table 1). The mean serum progesterone concentration gradually decreased from $60^{\text {th }}$ day $(3.628 \pm 0.067 \mathrm{ng} / \mathrm{ml}$; $3.558 \pm 0.129 \mathrm{ng} / \mathrm{ml})$ prepartum to 
significantly $(\mathrm{p}<0.05)$ on the day of calving $(0.408 \pm 0.075 \mathrm{ng} / \mathrm{ml} ; 0.629 \pm 0.110 \mathrm{ng} / \mathrm{ml})$ and it was gradually increased in trend from day of parturition to significantly $(\mathrm{p}<0.05)$ at $15^{\text {th }}$ day $(0.875 \pm 0.074$ vs. $1.211 \pm 0.176$ $\mathrm{ng} / \mathrm{ml})$ thereafter non-significantly $(\mathrm{p}>0.05)$ at $30^{\text {th }}$ day $(1.124 \pm 0.161$ vs. $1.052 \pm 0.114$ $\mathrm{ng} / \mathrm{ml}), 45^{\text {th }}$ day $(1.165 \pm 0.163 \mathrm{ng} / \mathrm{ml} ; 1.313 \pm$ $0.229 \mathrm{ng} / \mathrm{ml}$ ) and increased significantly $(\mathrm{p}<0.05)$ at $60^{\text {th }}$ day $(1.961 \pm 0.176 \mathrm{ng} / \mathrm{ml}$; $2.169 \pm 0.118 \mathrm{ng} / \mathrm{ml}$ ) postpartum in pregnant and non-pregnant groups of buffaloes, respectively (Table 1).

The pooled mean serum progesterone concentration in the present study, was found significantly $(\mathrm{p}<0.05)$ decreased from $60^{\text {th }}$ day $(3.603 \pm 0.061 \mathrm{ng} / \mathrm{ml})$ prepartum to lowest $(0.486 \pm 0.065 \mathrm{ng} / \mathrm{ml})$ on the day of calving and significantly $(\mathrm{p}<0.05)$ increased from $15^{\text {th }}$ day $(0.992 \pm 0.084 \mathrm{ng} / \mathrm{ml})$ till $60^{\text {th }}$ day $(2.034$ $\pm 0.122 \mathrm{ng} / \mathrm{ml}$ ) postpartum. The declined trend in plasma progesterone level during late gestation and lowest on the day of calving was in agreement with Smith et al., (1973) in Holstein heifers, Arora and Pandey (1982) in Murrah buffaloes, Sawada et al., (1988) in cows, El-Massry et al., (1997) in buffaloes, Habeeb et al., (1999) in Friesian cows, Chaiyabutr et al., (2000) in crossbred cattle, Ishikawa et al., (2004) in HF cows, Cernescu et al., (2010) in cows, Mostafa et al., (2014) in crossbred cows and Patel (2014) in HF crossbred cows. Moreover, Estergreen et al., (1967) suggested that corpus luteum was the main source of progesterone during pregnancy in cows. Huffmann et al., (1976) reported that uterine vein of cow did not make net contribution of circulating level of progesterone and there was no significant secretion from placenta into the foetal compartment. Therefore, it appears that decline in progesterone concentration before parturition may well have been resulted due to the regression of corpus luteum, which is probably brought about by $\mathrm{PGF}_{2 \alpha}$ at last stage in buffaloes as demonstrated in cows. In addition to this, vitamin $\mathrm{E}$ and selenium affect reproductive tissue through their antioxidant role as well as involvement in prostaglandin synthesis. Vitamin $\mathrm{E}$ has been implicated in the control of phospholipase $\mathrm{A}_{2}$ activity, which is responsible for cleaving arachidonic acid from membranes phospholipids for synthesis of prostaglandins (Robinson et al., 2006). Selenium preferentially accumulates in ovary, pituitary, placenta and adrenal glands suggesting specific requirements for selenium in these tissues for proper function (Hefnawy and Tortora, 2010). These aforesaid findings were in accordance with the concept of progesterone "block" being removed from the myometrium before or during the progress of parturition (Yannone et al., 1968) and these findings may be attributed to present study in which higher $(3.660 \pm 0.080$ vs. $3.547 \pm 0.094$ $\mathrm{ng} / \mathrm{ml}$ ) level of progesterone was observed at $60^{\text {th }}$ day in vitamin E and Selenium treated and control groups that was declined to the lower level $(0.456 \pm 0.076$ vs. $0.515 \pm 0.110 \mathrm{ng} / \mathrm{ml})$ at parturition as compared to control group.

Moreover, the overall trend of prepartum and postpartum progesterone profile found in buffaloes coincided well with that reported by Smith et al., (1973), who observed progesterone concentration remained high until 2 day prepartum $(7.6 \pm 0.9 \mathrm{ng} / \mathrm{ml})$ that fell down to $3.0 \pm 0.7 \mathrm{ng} / \mathrm{ml}$ at one day prepartum and to $0.6 \pm 0.1 \mathrm{ng} / \mathrm{ml}$ at parturition there after remained near this low level for 9 days postpartum in Holstein heifers. Similarly, the progesterone $\left(\mathrm{P}_{4}\right)$ concentration gradually decreased from 60 days $(4.0 \pm 0.2 \mathrm{ng} / \mathrm{ml})$ to 5 days $(2.0 \pm 0.2 \mathrm{ng} / \mathrm{ml})$ before parturition, thereafter rapidly decreased from 3 days $(1.6 \pm$ $0.1 \mathrm{ng} / \mathrm{ml})$ to the day of parturition $(0.11 \pm$ $0.01 \mathrm{ng} / \mathrm{ml}$ ) and remained at low level of less than $1 \mathrm{ng} / \mathrm{ml}$ between the day of parturition and 24 days postpartum in Holstein-Friesian cows (Ishikawa et al., 2004). 
Table.1 Mean serum Progesterone $\left(\mathrm{P}_{4}\right)$ levels $(\mathrm{ng} / \mathrm{ml})$ at different fortnightly intervals peripartum in antioxidant treated and control groups as well as pregnant and non-pregnant groups of Surti buffaloes (Mean \pm SE)

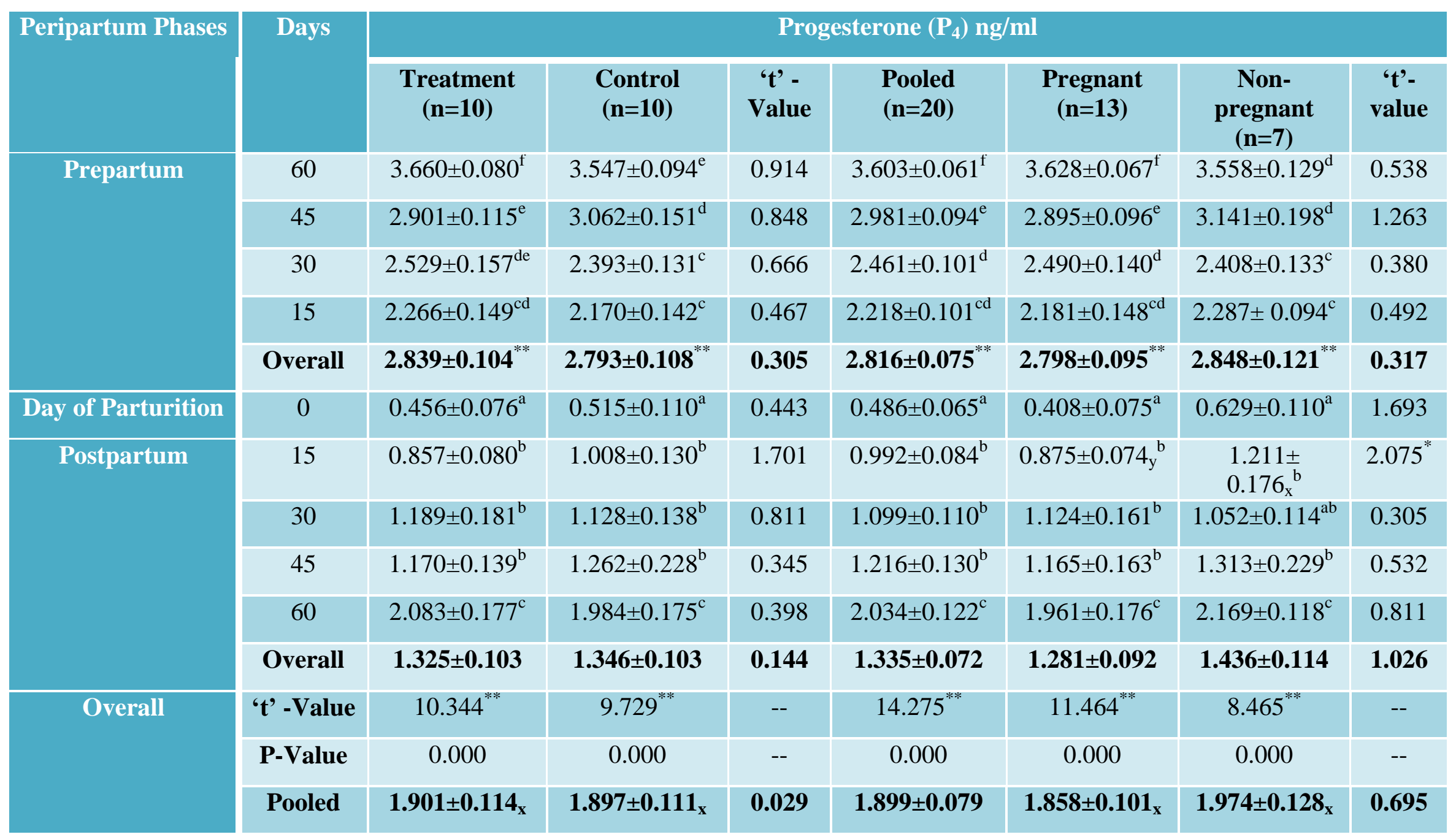

Means bearing different superscripts $(\mathrm{a}, \mathrm{b}, \mathrm{c})$ within a column (between phase intervals) differ significantly $(\mathrm{p}<0.05)$. Means bearing different subscripts $(\mathrm{x}, \mathrm{y}, \mathrm{z})$ within a row (between groups) differ significantly $(\mathrm{p}<0.05) ;{ }^{* *} \mathrm{p}<0.01$ between pre- and post-partum phase. 
Pargaonkar and Kaikini (1989) reported the level of progesterone in non-descript cows during 280 days of pregnancy and $5^{\text {th }}$ day postpartum as $5.90 \mathrm{ng} / \mathrm{ml}$ and $0.23 \mathrm{ng} / \mathrm{ml}$, respectively corroborated well with the present study.

In addition to this, the findings of linear increased in plasma progesterone concentration from parturition to postpartum period in the present study were also in close agreement with the reports of Edgerton and Hafs (1973) and Echternkamp and Hansel (1973) in non-suckled dairy cows; Pahwa and Pande (1983) in Murrah buffaloes, who all reported decreased progesterone level on the day of calving that increased linearly after parturition to rise with appearance of ovarian follicular activity.

Significant increase in progesterone occurred by $15^{\text {th }}$ day postpartum in the present study. These deviations from low level after parturition probably resulted from follicular luteinization or adrenal contribution (Wagner et al., 1969), since the postpartum level of progesterone remained low until the initiation of CL formation following ovulation (Echternkamp and Hansel, 1973). Short (1962) suggested that ovarian follicles could be a significant source of progesterone at 5 to 7 day after calving, but no such evidence exists in buffalo so far. Similarly, Edgerton and Hafs (1973) reported a linear increase in plasma progesterone concentration at one week to eight weeks postpartum in nonsuckled dairy cows, whereas it remained at a low level $(<0.3 \mathrm{ng} / \mathrm{ml})$ from parturition until first oestrus postpartum in non-suckled cows (Echternkamp and Hansel, 1973). Arora and Pandey (1982) recorded the lowest overall mean level of progesterone on the day of parturition, followed by a significant $(p<0.05)$ increase by day $16^{\text {th }}$ postpartum in Murrah buffaloes. Similarly, Pahwa and Pandey (1983) and Khasatiya et al., (2006) in buffaloes, and Patel et al., (2013), and Patel (2014) in cows also reported increased progesterone level around $15^{\text {th }}$ day postpartum. While, Smolders et al., (1996) reported progesterone concentration first time increased on $28^{\text {th }}$ day after calving and the level was found increased around $30^{\text {th }}$ day postpartum by others (Cernescu et al., 2010) and very much earlier transient increased trend of mean plasma progesterone concentration as $0.74 \pm 0.09 \mathrm{ng} / \mathrm{ml}$ and $1.01 \pm$ $0.12 \mathrm{ng} / \mathrm{ml}$ at $6 \mathrm{hrs}$ and $24 \mathrm{hrs}$ postpartum from the day of parturition, respectively as compared to present study has been reported by Patel et al., (2013) in HF cows.

Further, the explanation for abrupt increasing progesterone trend at $15^{\text {th }}$ to $30^{\text {th }}$ day postpartum might be attributed to early onset of follicular activity and ovulation contra lateral to the gravid horn or might be due to gradual rise in progesterone prior to the first postpartum estrus (Pope et al., 1969). Moreover, the source of this progesterone had not been elucidated, since there were apparently no functional corpora lutea present, it was conceivable that either luteinized follicles or adrenal glands might be responsible for the pre-estrual progesterone secretion. While, Callahan et al., (1971) reported that from day 8 to 20 postpartum size of ovaries increased in normal dairy cows. The sudden increasing serum progesterone concentration trend observed at $15^{\text {th }}$ to $30^{\text {th }}$ day after calving might give some clue on hidden follicular phenomenon that usually take place postpartum. Similarly, Smolders et al., (1996) also reported first increase in progesterone by about 28 days after calving and in 28 per cent of the cows, first oestrus cycle was normal with luteal phase of 12-17 days, but at the second cycle, 56 per cent of cows had a normal luteal phase.

In addition to this, mean serum progesterone concentration increased $(>1 \mathrm{ng} / \mathrm{ml})$ from the 
day $30^{\text {th }}$ postpartum to the day $45^{\text {th }}$ postpartum in the present study, might be due to establishment of normal pattern of progesterone secretion in cyclic animals. These findings were supported by Tegegne $e t$ al., (1993), who observed the African Zebu cows that cycled earlier expressed irregular and short-lived progesterone rises $(>1 \mathrm{ng} / \mathrm{ml})$. In the present study, buffaloes supplemented with injectable vitamin $E$ and Selenium at $60^{\text {th }}$ day, $45^{\text {th }}$ day, $30^{\text {th }}$ day, $15^{\text {th }}$ day before parturition and $15^{\text {th }}$ and $30^{\text {th }}$ day after parturition had higher pregnancy rate as compared to control group of Surti buffaloes (80 vs. $50 \%$ ), suggesting little bit earlier onset of follicular activity with higher conception rate in treated group.

\section{Acknowledgements}

Authors are grateful to Dean, College of Veterinary Science \& AH., Navsari Agricultural University, Navsari and all the staff of Department of Gynaecology \& Obstetrics for providing facilities and support to complete the present investigation.

\section{Conflict of interest statement}

Authors declare that they have no conflict of interest.

\section{References}

Arora, R.C. and Pandey, R.S. (1982). Changes in peripheral plasma concentrations of progesterone, estradiol-17 $\beta$, and luteinizing hormone during pregnancy and around parturition in the buffalo (Bubalus bubalis). General Comp. Endocrinol., 48: 403410.

Callahan, C.J., Erb, R.E., Surw, A. H. and Randel, R.D. (1971). Variables influencing ovarian cycles in postpartum dairy cows. J. Anim. Sci., 33:1053-1059.

Cernescu, H., Onita, P., Knop, R., Ionescu, C., Zarcula, S. and Groza, E. (2010). The metabolic and hormonal profile on peripartal Periode in cow. Lucrări Stiintifice Medicină Veterinară, 43: 1-8.

Chaiyabutr, N., Preuksagorn, S., Komolvanich, S. and Chanpongsang, S. (2000). Plasma levels of hormones and metabolites as affected by the forages type in two different types of crossbred Holstein cattle. Asian-Aust. J. Anim. Sci., 13(10): 1359-1366.

Drackley, J.K. (1999). Biology of dairy cows during the transition period: the final frontier? J. Dairy Sci., 82: 2259-2273.

Echternkamp, S.E., and Hansel, W. (1973). Concurrent changes in bovine plasma hormone levels prior to and during the first postpartum estrous cycle. J. Anim. Sci., 37: 1362 - 1370.

Edgerton, L.A., and Hafs, H.D. (1973). Serum luteinizing hormone, prolactin, glucocorticoid and progestin in dairy cows from calving to gestation. J. Dairy Sci., 56: 451-458.

EL-Massry, K.A., Yousef, H.M. and Fargaly, H.A. (1997). Hormonal pattern in Egyptian buffaloes in relation to their productivity. Buffalo J., 2:147-156.

Estergreen, V.L., Frost, D.L., Gomez, W.R., Erb, R.E. and Bullard, L.F. (1967). Effect of ovariectomy on pregnancy maintenance and parturitionin in dairy cows. J. Dairy Sci., 50: 129-135.

Fainaru, O., Almog, B. and Pinchuk, I. (2002). Active labour is associated with increased oxidisibility of serum lipids ex vivo. BJOG. 109(8): 938-41.

Habeeb, A.A.M., Yousef, H.M., Zahed, S.M. and E-Ekhnawy, K.I. (1999). Female sex hormones and some blood components in relation to progress of pregnancy, fetal growth, parturition and 
stage of lactation in Friesian cows. Egyptian J. Appl. Sci., 14:443-461.

Harrison, J.H. and Conrad, H.R. (1984). Effect of selenium intake on selenium utilization by the non-lactating dairy cow. J. Dairy Sci., 67: 219-223.

Hefnawy, A.G. and Tortora-Perez, J.L. (2010). The importance of selenium and the effect of its deficiency in animal health. Small Ruminant Res., 89: 185192.

Huffmann, B., Wagner, W. C. and Jimenez, T. (1976). Free and conjugated steroids in maternal and fetal plasma in the cow near term. Biol. Reprod., 14, 126-133.

Ishikawa. Y., Nakada, K., Hagiwara, K., Kirisawa, R., Iwai, H., Moriyoshi, M. and Sawamukai. (2004). Changes in Interleukin-6 concentration in peripheral blood of pre- and postpartum dairy cattle and its relationship to postpartum reproductive diseases. $J$. Vet. Med. Sci., 66: 1403-1408.

Jie, J.L., Douglas, S.J., Drago, R. and Bruce, D.R. (2004). Contemporary Drug Synthesis. John Wile \& Sons Inc Hoboken, New Jersey, pp 397.

Khasatiya, C.T., Kavani, F.S., Dhami, A.J., Derashri, H. J., Panchal, M.T. and Desai, P.M. (2006). Studies on puerperal events and reproductive efficiency following hormone therapy at day 42 postpartum in Surti buffaloes. Int. J. Agri. Biol., 8(1):132-137.

Margolin, Y., Aten, R.F. and Behram, H.R. (1990). Antigonadotropic and antisteroidogenic actions of peroxide in rat granulosa cells. Endocrinol., 127: 245-250.

Miller, J.K., Brzezinska-Slebodzinska, E. and Madsen, F.C. (1993). Oxidative stress, antioxidants, and animal function. $J$. Dairy Sci., 76: 2812-2823.

Mostafa, T.H., Elsayed, F.A., Ahmed, M.A. and Elkholany, M.A. (2014). Effect of using some feed additives (TW- probiotics) in dairy cow rations on production and reproductive performance. Egyptian J. Anim. Prod., 51(1):1-11.

Pahwa, G. S. and Pandey, R. S. (1983). Hormonal changes in postpartum blood plasma and milk of buffaloes (Bubalus bubalis). Anim. Prod., 37: 237-246.

Pargaonkar, D.R. and Kaikini, A.S. (1989). Studies on hormonal profiles of nondescript cows during various phases of reproduction. Indian J. Anim. Reprod., 10(2): 85-88

Patel, B.B., Patel, D.M., Patel, J.A., Dhami, A.J. and Sarvaiya, N.P. (2013). Effect of hormonal and herbal therapies at calving on puerperal events and plasma progesterone profile in Holstein Friesian cows. Indian J. Dairy Sci., 66: 102-108.

Patel, Rohit (2014). Effect of Methylergometrine, $\mathrm{PGF}_{2} \alpha$ and Utrovet during Puerperium period in Holstein Friesian cross-bred cows. M. V. Sc. Thesis, Navsari Agricultural University, Navsari, India.

Pope, G.S., Gupta, S.K. and Munro, I.B. (1969). Progesterone levels in the systemic plasma of pregnant, cycling and ovariectomized cows. J. Reprod. Fertil., 20:369.

Pressman, E.K., Cavanaugh, J.L. and Mingione, M. (2003). Effects of maternal antioxidant supplementation on maternal and fetal antioxidant levels: a randomized, double-blind study. Am. J. Obstet. Gynecol., 189(6): 1720-5.

Robinson, J.J., Ashworth, C.J., Rooke, J.A., Mitchell, I.M. and McEvory, T.G. (2006). Nutrition and fertility in ruminant livestock. Animal Feed Science and Technol., 126: 259- 276.

Sawada, T., Kimura, E., Fujimoto, Y., Matsunaga, H. and Mori, J. (1988). Plasma estrone, estradiol-17 $\beta$ and progesterone levels during late 
pregnancy and parturition in dairy cattle. Jpn. J. Vet. Sci., 50: 654-658.

Seagerson, E.C. and Libby, D.W. (1982). Ova fertilization and sperm number per fertilized ovum for selenium and vitamin E treated Charolais cattle. Theriogenology, 17: 333-341.

Short, R, V. (1962). Steroids present in the follicular fluid of the cows. $J$. Endocrinol., 23: 401 - 411.

Smith, V.G., Edgerton, L.A., Hafs, H.D. and Convey, E.M. (1973). Bovine serum estrogens, progestins and glucocorticoids during late pregnancy, parturition and early lactation. J. Anim. Sci., 36: 391-396.

Smolders, E.A.A., Thesingh, M.S.H., Vos, P.L.A.M. and Willemse, A.H. (1996). Resumption of the ovarian cycle after calving. Anim. Breed. Abstr., 65(3): 1314.

Sugino, N., Takiguchi, S. and Kashida, S. (2000). Superoxide dismutase expression in the human corpus luteum during the menstrual cycle and in early pregnancy. Mol. Hum. Reprod., 6(1): 19-25.

Tegegne, A., Geleto, A. and Kassa, T. (1993). Short luteal phases and ovulations without oestrus in primiparous Barona (Bos indicus) cows in the central high land of Ethiopia. Anim. Reprod. Sci., 31(1-2): 21-31.

Wagner, W.C., Saatman, R. and Hansel, W. (1969). Reproductive physiology of the postpartum cow II. Pituitary adrenal and thyroid function. J. Repro. Fert., 18: $501-508$.

Weiss, W.P. and Spears, J.W. (2006). Vitamin and trace mineral effects on immune function of ruminants. In: Sejrsen, K., Hvelplund, T., Nielsen, M.O. (Eds.), Ruminant Physiology. Wageningen Academic Publishers, Utrecht, The Netherlands, pp. 473-496.

Yannone, M.E., McCurdy, J.R. and Goldfren, A. (1968). Plasma progesterone levels in normal pregnancy labor and the puerperium. Am. J. Obstet. Gynecol., 101: 1058 - 1063.

\section{How to cite this article:}

Modi, L.C., C.T. Khasatiya, Sandhya Chaudhary, N.F. Chaudhari, C.F. Chaudhari and Falguni Modi. 2018. Effect of Antioxidant Administration during Transient Period on Progesterone Profile in Surti Buffaloes. Int.J.Curr.Microbiol.App.Sci. 7(09): 1504-1512. doi: https://doi.org/10.20546/ijcmas.2018.709.180 